Revue Française de Civilisation Britannique

\title{
From Public Service to Public Interest and Beyond in British Broadcasting Regulation
}

La Régulation du modèle britannique de l'audiovisuel : par delà le service public et l'intérêt public

\section{Simon Dawes}

\section{(2penEdition}

\section{Journals}

Electronic version

URL: https://journals.openedition.org/rfcb/7253

DOI: $10.4000 /$ rfcb.7253

ISSN: 2429-4373

\section{Publisher}

CRECIB - Centre de recherche et d'études en civilisation britannique

\section{Electronic reference}

Simon Dawes, "From Public Service to Public Interest and Beyond in British Broadcasting Regulation", Revue Française de Civilisation Britannique [Online], XXVI-1 | 2021, Online since 05 December 2020, connection on 05 January 2022. URL: http://journals.openedition.org/rfcb/7253 ; DOI: https://doi.org/ $10.4000 /$ rfcb.7253

This text was automatically generated on 5 January 2022.

\section{c)}

Revue française de civilisation britannique est mis à disposition selon les termes de la licence Creative Commons Attribution - Pas d'Utilisation Commerciale - Pas de Modification 4.0 International. 


\title{
From Public Service to Public Interest and Beyond in British Broadcasting Regulation
}

\author{
La Régulation du modèle britannique de l'audiovisuel : par delà le service public \\ et l'intérêt public
}

Simon Dawes

\section{Introduction}

1 The BBC is widely held to be the ideal type for public service broadcasters; informing, educating and entertaining the public, independent of both government/state and commercial /private interests, and, as the most trusted source of news in an environment increasingly typified by mistrust in politics and the media, a bastion of objective, neutral and unbiased news ${ }^{1}$. The institution has been widely criticised, however; notably by the right-wing commercial media who accuse it of left-wing bias, and critical media academics that criticise it for conservative or liberal bias. Further, the extent to which the $\mathrm{BBC}$ has ever served the public interest, and to which the notion of public service broadcasting has done more to depoliticise the public rather than contribute to active citizenship, have been the focus of debate in more recent years. ${ }^{2}$ Indeed, the term 'public service' has often been used strategically to serve the self-interests of various groups, while even (original director general of the BBC) John Reith's definition of 'public service' has been shown to resemble 'public utility' more than 'public sphere', addressing it almost exclusively, as he does, in terms of universal access and engineering quality rather than citizenship or broadcasting's importance for democracy. ${ }^{3}$

2 This article demonstrates the ways in which the British state's initial interest in ensuring 'public control' of broadcasting in the 'national interest' in the 1920s shifted to the more familiar ethos of 'public service', and the ways in which that ethos became reinterpreted and increasingly marginalised over time, ultimately becoming 
incorporated into the wider, more competition-friendly framework of the 'public interest'. The final section also shows the ways in which the paradigm has continued to shift more recently, with an increasing focus on achieving 'public purposes' and 'public value'.

\section{Broadcasting Regulation in the UK}

3 This article focuses on the policy, legislation and regulation of broadcasting in the UK whereby that is understood as the way in which public service institutions, and the broadcasting sector as a whole, are governed in terms of specific rules as well as broad ideas. While policy refers more to the broad ideas and general assumptions (often regarding understandings of the national interest and the role of public broadcasting and its relation to private enterprise, media freedom and the free market), legislation refers to general issues (such as privacy and competition), and regulation to the agencies and rules regarding broadcasting as a particular institution or sector. ${ }^{4}$

Broadcasting regulation concerns the political relations of broadcasting to government, parliament and the public (1977 Annan Report). In the UK, broadcasting has been shaped by the analyses, recommendations and proposals presented in official reports, consultative Green Papers, policy statements in White Papers, and adopted legislation in Bills (draft Acts) and Acts of Parliament..$^{5}$ Initial regulation focused on the interpretation of broadcasting's power and the extent to which it needed to be controlled, and on the classification of spectrum, whether understood as public resource or private property. ${ }^{6}$

Whereas the approach to the self-regulation of the press in the UK has, for over 150 years, been from the perspective of media law, broadcasting has traditionally been regulated in terms of media organisation, funding and ownership. ${ }^{7}$ The legal approach to press regulation presupposes a market, and frames debate in terms of the paternalistlibertarian dichotomy of privacy versus free speech, wherein issues of ownership are side-lined and the 'public interest' functions as little more than a defence for particular activities carried out within a market framework. The regulatory approach towards broadcasting, on the other hand, has traditionally been a compromise between conventional left and liberal-pluralist approaches, directly addressing issues of ownership and interrogating the assumptions behind the free press rhetoric of the traditional liberal-pluralist approach. And while the public interest-supplemented selfregulation of the press views newspaper readers primarily as consumers, the public service remit of broadcasters and the independent regulatory broadcasting environment has, in contrast, traditionally (at least) viewed audiences as citizens first, consumers second.

6 According to the dominant narrative of broadcasting history, there was relative international consensus on the need for some element of state involvement in the establishment and regulation of broadcasting. Across Europe, the general trend was to favour the public ownership and regulation of national resources and utilities, and broadcasting was no different. Although early developments with radio technology had been left unregulated in the US at the beginning of the 1920s, by 1927 it had become accepted even there that broadcasting was an exceptional case, and that state involvement, at least in the allocation of spectrum space, would be necessary. ${ }^{8}$ 
7 However, the dichotomous relationship between the (public service) broadcasting and (public interest) press freedom approaches to international media regulation became less distinct over the course of the $20^{\text {th }}$ century. Following the delegitimation of rationales for public regulation, processes of privatisation, deregulation, liberalisation and marketisation transformed the global broadcasting landscape from the late 1970s onwards. ${ }^{9}$

8 In the UK, attempts to address more popular tastes, as well as the representation of minority or marginalised groups and interests, coincided with broadcasting's acceleration into the corporate system..$^{10}$ Dismissing 'imagined unities of national culture' and abandoning the commitment to an undivided public good, when the Annan Committee met in 1977 it embraced Britain as a 'fractured cultural formation', breaking with the Pilkington Report's (1962) hostility towards advertising ${ }^{11}$ and replacing the ideal of public service with the principle of liberal pluralism..$^{12}$ Whereas 'the concept of public service is elaborated in all broadcasting reports before that of the Annan Committee', broad consensus on the public interest is abandoned and replaced by the principle of a free marketplace in the private realm, 'in which balance could be achieved through the competition of a multiplicity of independent voices'. ${ }^{13}$ Since the Peacock Report (1986) more definitively shifted the perspective from which broadcasting is regulated (to that of the 'wrong end of the telescope'), controls on market concentration and cross-media ownership have been weakened through legislation, such as the Broadcasting Act (1996) and the Communications Act (2003), ${ }^{14}$ while even the $\mathrm{BBC}$ themselves have introduced internal markets. ${ }^{15}$ This process has undeniably been accompanied by a change in language, ${ }^{16}$ with 'customers' and 'consumers' replacing earlier appellations (such as 'viewer' or 'citizen'), as well as by the quantification of quality, and the increasing dependence upon quantitative measures of performance, league tables and auditing, which privilege quantifiable performance and ignore that which is difficult to quantify. ${ }^{17}$ Furthermore, New Labour's desire to correct the market distortion of PSB institutions led to a recasting of 'public service'18 in terms of programming rather than institutions, as well as the reconceptualisation of the BBC's relation to the rest of the broadcasting environment, to the extent that the $\mathrm{BBC}$ is no longer regulated as an institution in its own right, but only insofar as it is tied to its commercial rivals. ${ }^{19}$ Although praise continues to be offered for PSB - and even the BBC - in regulatory documents such as the White Paper (2006) and Green Paper (2015), such praise is now almost entirely from the perspective of market competition. ${ }^{20}$

9 As such, the regulation of broadcasting in the UK has tended to be framed in terms of a debate between those who favour 'public service' remits and those whose faith lies in the invisible hand of the free market, whether these distinct perspectives are conceived as political-social and economic, ${ }^{21}$ the cultural and economic 'ends of the telescope', ${ }^{22}$ social democratic and neoliberal, ${ }^{23}$ or social values-led and economy-driven ${ }^{24}$ approaches. The former has been preoccupied by the protection of broadcasting from corporate power and market logic, emphasises the importance of broadcasting for democracy, and considers the contemporary issue of digitisation in terms of egovernment, the 'digital divide', achieving 'universal digital access', and mitigating social exclusion. The latter perspective, on the other hand, is treated as continuous with the Peacock Report (1986), and is concerned with competition, market failure, the limits/scope of public intervention/funding and, of late, the role of digital media in 
boosting the UK's prosperity and competitiveness. Issues include replacing the licence fee with subscription, and limiting PSB to market failure provision, with benefits seen in terms of consumer choice and interactivity. ${ }^{25}$ Although the economic considerations and liberal, or even neoliberal, arguments for press freedom and a free market in broadcasting have been considered regularly throughout the history of broadcasting's regulation ${ }^{26}$, the balance between the two approaches has tipped in their favour in recent decades, with the Thatcher-appointed Peacock Committee (1986) widely regarded as a stay of execution for the $\mathrm{BBC}$, which has been on death row ever since.

During the 1980s, the scholarly critique of broadcasting shifted gear. This was in the political context of Thatcher's ideological zeal for privatisation and her conflicts with the BBC, coupled with the expansion of Murdoch's media empire and his wars with the printing unions. The two were not unrelated, and there has been much controversy over the 'secret deals' between the two that allowed Murdoch to expand his operations without being referred to the Monopolies and Mergers Commission, and the apparent trade-off between police and government support for Murdoch, and his newspapers' support for Thatcher. Although criticism of the BBC continued, and while a critique of the political influence of Murdoch and News Corp, as well as the collusion between government and corporate players, and of the media's failure to live up to the ideal of a political watchdog holding power to account, represented nothing new in themselves, what was new was the merging of theoretical perspectives, the emergence of a new array of normative concepts, and a political motivation to defend a public service regulated environment. Many left-leaning media scholars in the UK were 'tiring of Frankfurt School-style critique and seeking, instead, to advocate a positive vision for public institutions', ${ }^{27}$ and the association of PSB with new concepts, such as the 'public sphere' ${ }^{28}$ and 'citizenship', armed proponents with the emancipatory arguments they needed to challenge those of the 'privatising marketeers'. ${ }^{29}$

It no longer seemed appropriate or adequate to critique broadcasting generally while Thatcher threatened the $\mathrm{BBC}$, and the liberal pluralist arguments in favour of press freedom, coupled with the free marketeers' critique of PSB, threatened to put an end to the BBC and the European model of PSB. There was a shift towards critiquing instead how the media was regulated, and in applying normative criteria to assess the democratic effectiveness of regulation ${ }^{30}$. The critique was applied to both the state/ government broadcasting model and the free market model, finding in favour, and stressing the importance, of an independently regulated, PSB environment. Although criticism of the $\mathrm{BBC}$ has continued (including evidence demonstrating its right-wing bias with regards to strikes, the Israel/Palestine conflict, Scottish independence and Jeremy Corbyn), critique of broadcasting has tended to be more in terms of its failures in contributing to the public sphere, rather than its role as an Ideological State Apparatus.

The distinction between a PSB model regulated in the interests of citizens, and a commercial model driven by the interests of advertisers, shareholders and, ostensibly, consumers ${ }^{31}$ has been entrenched in critical scholarship on British broadcasting since this period.

But it is interesting to look closely at the ways in which terms such 'public service' and 'public interest' are used in the documents that set out how the broadcasting institutions and sector are to be regulated. Indeed, the increasing preference for the term 'public interest' (and more recently, 'public value') constitutes a shift towards a 
more commercial outlook, wherein the role of 'public service' broadcasting is increasingly diminished and reconstituted in terms of market failure.

Broadcasting regulation in the UK assumed an ethos of public service between the 1920s and the 1970s. Although the earliest reports - Sykes (1923) and Crawford (1926) had focused on ensuring that PSB was set up in a way that guaranteed its independence (the independence of what was at the time just one institution) and the service of the 'national interest', little attention was paid to debating these issues between then and the 1960s/1970s, both because governments had been more concerned with technical matters, and because there had been little disagreement over what constituted the national interest. The Annan Report (1977) remains the last example of a formal, systematic attempt to examine the role, future and contribution of broadcasting in cultural rather than economic terms, coinciding as it did with the political turning point of the corporatism of the 1960s and 1970s giving way to the individualism, market liberalism and private enterprise of the 1980s. It represents an ambiguous turning point, however, in that, whereas "the concept of public service is elaborated in all broadcasting reports before that of the Annan Committee", the ideal of broad consensus on the public/national interest is subsequently abandoned by Annan and replaced by the principle of a free marketplace in the private realm, "in which balance could be achieved through the competition of a multiplicity of independent voices". ${ }^{32}$ The later Peacock Report's (1986) adoption of an economic perspective and privileging of consumer sovereignty is widely deemed to have cemented this shift in regulatory framework, while the more recent appropriation of the concept of 'public value' has led to debate on the extent to which it constitutes yet another 'paradigm shift'.

Examining the ways in which such concepts have been reconfigured throughout the history of broadcasting regulation, however, this article offers a way of understanding their significance in terms of long-term, ongoing and unresolved problematisations, and questions the extent to which we can clearly distinguish between social and economic 'paradigms' or perspectives, focusing on the ongoing reconfiguration of the terms 'public control', 'public service', 'public interest' and, more recently, 'public value'.

From Public Service to Public Interest

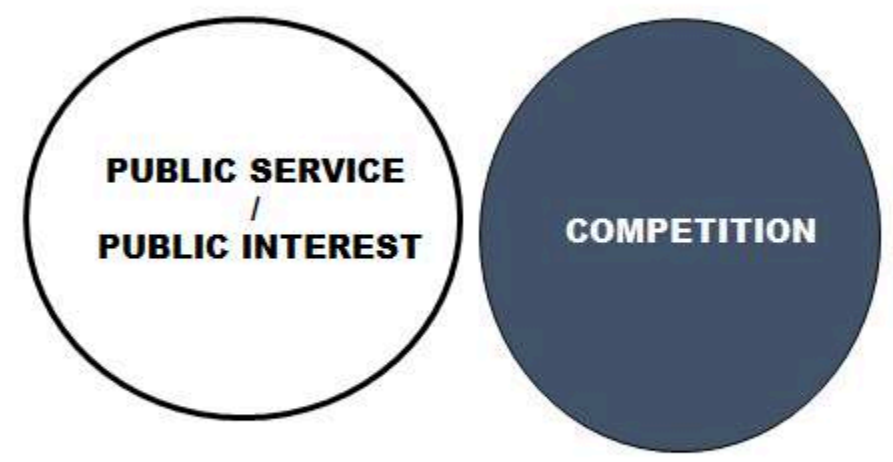



opposing philosophies', they were 'deceptive slogans', and the antithesis between them was a 'gross over-simplification of a complex and continuing problem' ${ }^{39}$. Pilkington critiqued both the 'give the public what it wants' approach and the 'give the public what [the broadcaster] thinks is good for it' alternative as 'deceptive' and 'patronising', arguing that the former 'claims to know what the public is, but defines it as no more than the mass audience', limiting the public's choice to 'the average of experience', while the latter claims to know what would be in the public's best interests. ${ }^{40}$ Both approaches are thus accused of reducing the public to a passive and undifferentiated mass. In critiquing both these contrasting philosophies and the effort to choose between them, the Report argued that there was, however, 'an area of possibility between the two', and that the duty of broadcasters should rather be to acknowledge that 'what the public wants and what it has the right to get is the freedom to choose from the widest possible range of programme matter. Anything less than that is deprivation'. ${ }^{41}$ This would be significant for the future definition of the 'public' 
(increasingly as consumers rather than citizens) and for the emergence of 'choice' as a key issue, but this statement also has consequences for 'public service' and 'public interest'. In the distinction between 'what the public wants' and the 'what [the broadcaster] thinks is good for it', therefore, we can see a reconfiguration of the 'public interest' as the 'right and freedom to choose', and of 'public service' as the duty to provide choice to the public.

The Report further maintained that broadcasters should be given the 'greatest possible freedom' to provide such a public service, ${ }^{42}$ and proposed that 'competition in good broadcasting', ${ }^{43}$ between the two broadcasters of the time, although not competition of any other kind, would best support this redefinition of PSB's duty to its public. 'Public service' becomes, therefore, less an obligation or constraint than something that broadcasters would naturally provide given the right conditions and absence of constraints, while its provision becomes dependent upon competition (in good broadcasting, rather than for audiences or advertising revenue).

The shift away from the 'patronising' approaches of both the BBC and the commercial PSBs towards a focus on choice in the public interest was furthered by both the Annan Report (1977), with its recommendation to establish a fourth public-private channel to cater for the marginal interests of a diverse public (and emphasising Pilkington's emphasis on accommodating choice within a public service framework), and the Hunt Report (1982) on cable TV. Problematising the early antithesis between PSB and commercial TV in the context of cable, the latter Report argued that both approaches were essential to what it called the 'wider public interest', which could best be met by encouraging the development of cable TV as a supplement to a safeguarded PSB. ${ }^{44}$ In considering the arrangements under which PSB and cable could co-exist without damaging the former or inhibiting the latter, ${ }^{45}$ PSB is shown to provide a 'balanced service for the country as a whole', while cable is 'all about widening the viewer's choice'. ${ }^{46}$ Commercial cable TV does not have to be incorporated into a public service framework, therefore, but neither should it be seen as antithetical. Instead, it widens choice (beyond that which PSB provides), widens the public interest (beyond the remit of public service broadcasters), and supplements the main public service framework (by this stage already accommodating multiple forms of ownership).





decouple 'public service' (balanced content) from the 'public interest' (balanced content supplemented by choice), to undermine the previous contrast between the 'public interest' and the self-regulated market, and to see the 'wider public interest' in terms of accommodating both PSB and the market. As PSB is also linked with the 'country as a whole', and the cable market with the individual 'viewer's choice', the link between the 'public interest' and the nation/public (rather than the individual) is therefore also weakened, and the contrast between the 'public interest' and individual's private interests softened. Rather, the 'public interest' is 'widened' to accommodate both individual choice and a balanced service to the aggregate public, while PSB becomes merely a 'counter-balance to fears about concentration of ownership and the absence of diversity of views'. ${ }^{47}$

Although the Peacock Report (1986) certainly represented a clear break from earlier reports in approaching broadcasting from an economic perspective, critically acknowledging the long-term evolution of the relation between 'public service' and 'public interest' throughout the history of broadcasting regulation allows us to put its significance into perspective. When Peacock approached broadcasting in terms of 'consumer sovereignty', it made 'public interest' explicitly synonymous with the 'interests of viewers and listeners', ${ }^{48}$ understood principally as 'consumers'. Although it argued that the 'public interest', thus understood, was therefore best served through both public service and the market, it evaluated PSB's successes and failures in terms of the extent to which it replicated a 'true consumer market'. 'Public service' was thus reconfigured as a temporary solution to the conundrum of how to ensure the 'public interest' (i.e. 'consumer sovereignty' and a 'true consumer market') in the context of spectrum scarcity, and no longer as antonymous to commercialism.

Although the Report concurred with Pilkington that the essence of PSB institutions is to serve the interests of the public or society as a whole, as judged by the institutions themselves, Peacock argued that PSB 'can best be understood in relation to...consumer sovereignty and commercial laissez-faire', ${ }^{49}$ thus replacing the dichotomy of PSBcommercialism with a trichotomy of PSB-consumer sovereignty-commercialism. The Report also stated that "the fundamental aim of broadcasting policy should in our view be to enlarge both the freedom of choice of the consumer and the opportunities available to programme makers to offer alternative wares to the public". ${ }^{50}$ Peacock therefore also returns to Pilkington's definition of 'public service' as an opportunity for, rather than a restriction on, broadcasters, and no longer a case of providing set content for a passive public, but of providing choice, albeit for a public understood as consumers. ${ }^{51} \mathrm{Further}$, although the Report understands PSB as 'any major modification of purely commercial provision resulting from public policy', ${ }^{52}$ and thus presumes that broadcasting's natural state is one of 'purely commercial provision', it finds both the free market advertising model and the PSB licence-fee model wanting in terms of guaranteeing 'consumer sovereignty', and accuses them jointly of serving more the interests of producers than of consumers. ${ }^{53}$

Having defined 'public service' in this way, its scope can be made to 'vary with the state of broadcasting, ${ }^{54}$ justifying the ongoing reconfiguration of PSB and tying it to a preexisting market. The Report maintains that, historically, PSB institutions have been 'necessary to provide the viewer and listener with what [they want] as a consumer', while the 'public service' ethos is described as a 'commitment to produce a wide range 
of high quality programmes to maximize consumer appreciation', ${ }^{55}$ and concludes that PSB has even done 'far better, in mimicking the effects of a true consumer market, than any purely laissez-faire system, financed by advertising could have done under conditions of spectrum shortage' ${ }^{56}$ At the same time, PSB's weakness (other than its vulnerability to political pressure because of its "dependence on public finance and regulation') is exposed as an 'absence of true consumer sovereignty... which only direct payment by viewers and listeners could establish" ${ }^{57}$ However, should a true consumer market be achieved, in which viewers and listeners express their preferences (and the intensity of their preferences) directly through subscription, then "the main role of public service could...be the collective provision...of programmes which viewers and listeners are willing to support in their capacity of taxpayers and voters, but not directly as consumers". ${ }^{58}$ This is the market failure definition of PSB: that while a true market may ultimately serve the consumer interest, PSB will still be required to serve the citizen interest. Public intervention and regulation are justified, however, not only in terms of 'our [i.e. the Committee's] sense of public service' (that is, the market failure approach to supplementing the market with service provision for 'citizens') ${ }^{59}$ but also to ensure an effective 'consumer market'. ${ }^{60}$ PSB is therefore justified because it ensures that both citizen and consumer interests are met. But PSB is here tied to programming rather than institutions (with well-documented consequences for the funding of the $\mathrm{BBC}$ ), and citizenship is reductively associated with voting and taxpaying, rather than any communitarian (or participatory) aspects.

26 Although advertising is criticised for failing to achieve 'standards of public accountability for the private use of public assets' ${ }^{16}$ both the advertising and licence fee models are rejected in favour of 'direct consumer choice', ${ }^{62}$ because they fail to achieve the 'welfare benefits theoretically associated with a fully functioning market'. ${ }^{63}$ The Report therefore recommends that broadcasting 'move towards a sophisticated market system based on consumer sovereignty', and to supplement this direct consumer market with the public financing of public service programmes for 'citizens and voters' ${ }^{\prime 64}$ - though the distinction between citizens and voters in this sense is unclear. Public Service thus becomes a supplement to the direct consumer market (and the public interest). Although its emphasis is on economic theory, consumer sovereignty and market failure, the Peacock Report retains an important role for citizens and PSB, and envisages a mixture of direct payments and public service grants, as well as of private enterprises and public corporation. ${ }^{65}$ And although the view of citizenship is reductive, the elaborated view of consumers provides a view of the public that is, in many ways, more active than in any previous (or indeed subsequent) report. ${ }^{66}$

\section{A New Paradigm? Public Purposes and Public Value}

Although Peacock is often credited with having ushered in an economic, consumeroriented, commercialisation of broadcasting, it is important to note the Report's critique of laissez-faire commercialism, and its distinctions between its own nuanced approach to consumer sovereignty and the private interests of advertising-financed commercial broadcasting; if only to highlight the relative neglect of these aspects from subsequent regulation. When ofcom later distinguished between 'social values-led' and 'economics-driven' approaches to broadcasting regulation, for instance, the latter was made to conflate the consumer and commercial approaches that Peacock had 
distinguished between, while the former was made to include them alongside public service. In this case, the social values-led approach is made to consider PSB as only a 'sub-set' of the public interest, "alongside, for example, healthy competition, [and]) a thriving commercial broadcasting sector", while the commercial sector is constructed as a prerequisite for, rather than an alternative to, PSB:67 'Understanding the Market'). Rhetorically, the two approaches are given equal weight and are evenly balanced in the regulator's unsurprising conclusion that the two approaches are 'not so different' after all, and that 'both approaches can, in fact, be captured in a wider economic framework which considers the maximisation of social welfare' ('Supporting Documents: A Conceptual Review'). ${ }^{68}$

Following Peacock's interpretation of the history of broadcasting regulation in terms of consumer interests, and its realignment of 'public service' with programming rather than with institutions, Ofcom saw broadcasting history as a matter of the expanding 'plurality of public service broadcasting provision', ${ }^{69}$ asserting that such 'plurality provision is in the public interest'. ${ }^{70}$ The aim to expand commercial TV while safeguarding PSB is therefore achieved by expanding the notion of PSB institutions. The 'major sources' of PSB programming are made to include not only the publicly-funded BBC, Channel 4 and commercial PSBs (ITV and Five), but also those 'commercial broadcasters that also provide content that meets PSB purposes', ${ }^{71}$ so reducing the difference between PSB and commercial institutions, and incorporating competition, PSB and the 'wider market' within the 'public interest'.

Because of the BBC's problematic position as a 'deliberate public policy intervention in the market' ${ }^{72}$ however, it is subsequently differentiated from that of the commercial PSBs, who are associated instead with the 'commercial services and wider industry'. While these broadcasters (who may or may not be competing to produce quality PSB programming) serve the interests of the 'public and the rest of the broadcasting world', ${ }^{73}$ the BBC's purposes are rewritten to include an explicit objective to sustain 'citizenship and civil society'. ${ }^{74}$ PSB's democratic function is thus re-inscribed in the institution of the $\mathrm{BBC}$, now more explicitly linked to citizenship and public service programming, while both the commercial PSBs and commercial broadcasters are associated with the provision of public service programming for the 'public' as well as commercial content for the 'rest'. This move was underlined again in the most recent White Paper's obsession with the BBC's 'distinctiveness' (over 150 references to variations on the word 'distinctive') $)^{75}$.

Further, 'competition regulation' arrangements are made whereby the BBC's citizenship and public service programming is regulated 'within a new market framework' by the newly established BBC Trust (and Ofcom) through a 'Public Value Test' (PVT).$^{76}$ Although 'public service' broadcasting is recognised as being in the public's 'affection' (now understood as 'public value') and in the 'public interest', it must nevertheless be 'balanced with consideration for competition' - which, of course, is also in the public interest. ${ }^{77}$

31 Proposed initially by the $\mathrm{BBC}$ itself as a "pre-emptive strike in the run-up to the charter renewal process", ${ }^{78}$ and subsequently taken up by the New Labour government and instilled in legislation, ${ }^{79}$ 'public value', it is acknowledged, is a hazy concept. It is used in UK broadcasting regulation, however, to cover the social and cultural (i.e. not economic) benefits of broadcasting (which have to be considered alongside good and bad economic effects). For the BBC, it relates to their own 'public purposes' - serving 
citizenship and civil society; promoting education and learning; stimulating creativity and cultural excellence; reflecting the UK, its nations, regions and communities; and bringing the world to the UK and the UK to the world - and their four 'drivers' - reach, quality, impact and value for money. The government of the time concurred that it relates to qualitative aspects such as those covered by the BBC's 'public purposes and priorities' and the value users place on the service - i.e. the public's 'feelings' - though they placed more emphasis on the importance of value for money of the licence fee. ${ }^{80}$

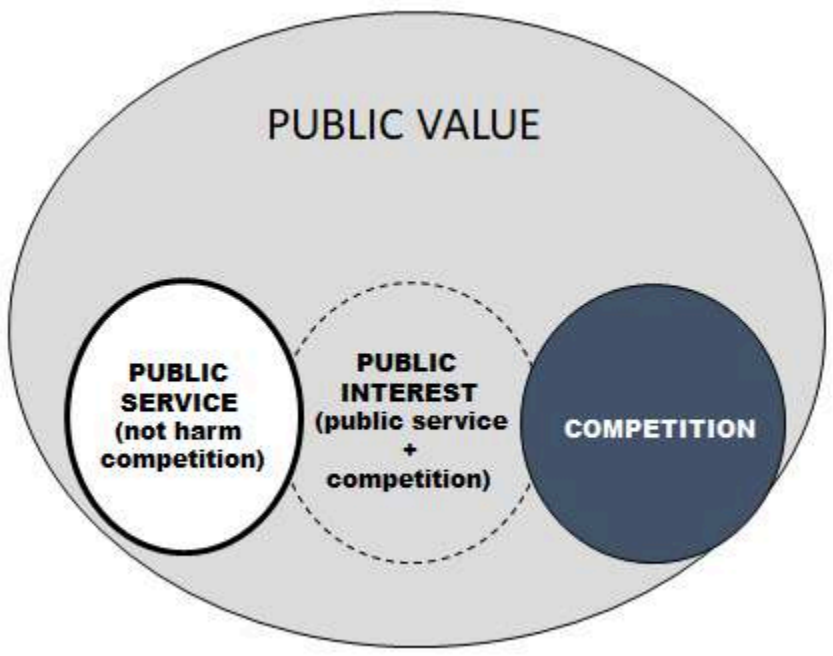

The concept of 'public value' comes from Mark Moore's proposal for an alternative to the 'new public management' (NPM) focus on the appropriation of performance indicators, market mechanisms and other aspects of the private sector. But Moore's canonical articulation of public value doctrine, which foregrounds the values of 'coproduction and contestation', poorly matches the BBC's status and circumstances, ${ }^{81}$ and the selective adoption of Moore's proposal by UK policymakers has seen it primarily as a methodology of performance measurement (and public management) instead of seeing public value as a process. ${ }^{82}$ In this context, although the public value has a 'general orientation to the user', potentially privileging accountability to users as 'citizens rather than as subjects or consumers' and their active role in the governance of the $\mathrm{BBC},^{83}$ the PVT demonstrates little more than the greater use and reliance on consumer research techniques. ${ }^{84}$ The BBC's own alternative rationale for PSB thus prioritises the balancing of consumer value maximisation with market impact assessments, ${ }^{85}$ rather than the citizenship aspect of their own public purposes.

While some have argued that the shift to 'public value' is a failed approach to policymaking, ${ }^{86}$ being neither a clear methodology for assessing value, nor a convincing or clear rhetorical alternative to 'public service' or 'public interest', and that it is more a strategic change of terminology and continuance of policy as usual, rather than a paradigm change in broadcasting regulation, ${ }^{87}$ it is important to look closely at how the term continues to be articulated with other concepts.

For instance, 'public value' continues to be important for the reconfiguration of 'public service' and 'public interest', with the most recent regulatory document using all three terms extensively: 'public service' (98 occurrences), 'public value' (34), and 'public interest' (28).$^{88}$ Here, 'public value' (for the benefit of viewers and listeners as both citizens and consumers) plus the avoidance of undue market impact together 
contribute towards the 'public interest' as evaluated by the PVT. ${ }^{89}$ This requires the BBC Trust to balance the 'public value' with a market impact assessment (carried out by itself for changes to existing services, and by Ofcom for new services). Because the PVT is always-already a balance between the public value and market impact, however, such qualitative issues are never allowed to stand for themselves, but are immediately imbricated within a qualitative-quantitative, and/or sociocultural-economic perspective. Further, the PVT is a misleading term, seeing as it is used to evaluate not the public value, but the public interest. Alternatives, such as 'public interest test' or 'public value and market impact test', would therefore be more accurate labels for this particular assessment.

\section{Conclusion}

This article has demonstrated the evolving rationale for broadcasting regulation in the UK, from an initial concern to balance public control with private enterprise, through changing interpretations and imbrications of public service and public interest, to the more recent privileging of public value. So, while the commercial PSBs are currently conflated with purely commercial TV, and the BBC explicitly linked with citizenship, the BBC-citizenship nexus remains framed within the same logic of market competition. While it is independently regulated in terms of the public interest, which is already a compromise of commercial, consumer sovereignty and public service perspectives, as well as a balance between this multiple perspective and its impact on the market, it is also prone to tertiary regulation by the competition regulator, which seeks to balance PSB with a competitive market. Competition and the market are therefore protected via three levels of $\mathrm{BBC}$ regulation: within the government's policy approach to the 'public interest' (a balance between PSB and the wider market), the BBC Trust's approach to testing 'public value' (which is always-already a balance between the 'public interest' and 'market impact') and ofcom's additional 'market impact' assessments. Despite the continued rhetorical foregrounding of the 'publicness' of the $\mathrm{BBC}$, therefore, the regulatory approach to the institution is better understood in terms of the slow rise of 'competition' as the predominant guiding principle.

\section{BIBLIOGRAPHY}

Barnett, S., 'Which End of the Telescope? From Market Failure to Cultural Value', in J. Cowling and D. Tambini (eds), From Public Service Broadcasting to Public Service Communications (Institute for Public Policy Research, 2002), www.ippr.org, accessed 01 June 2009.

Born, G., 'From Reithian Ethic to Managerial Discourse: Accountability and Audit at the BBC', Javnost: The Public 10:2 (2003).

Born, G., Uncertain Vision: Birt, Dyke and the Reinvention of the BBC (London, Vintage, 2005).

Coase, R.H., 'The Origin of the Monopoly of Broadcasting in Great Britain', Economica 14:55 (1947). 
Collins, R., 'Public Service versus the Market Ten Years on: Reflections on Critical Theory and the Debate on Broadcasting Policy in the UK', Screen 34:3 (1993).

Collins, R., 'Paradigm Found: The Peacock Report and the Genesis of a New Model of UK Broadcasting Policy', in T. O'Malley and J. Jones (eds.) The Peacock Committee and UK Broadcasting Policy (Hampshire, Palgrave Macmillan, 2009).

Curran, J., Media and Power (London, Routledge, 2002).

Curran, J and Seaton, J., Power Without Responsibility: The Press, Broadcasting, and New Media in Britain, (London, Routledge, 2003), $6^{\text {th }}$ edition.

Dawes, S., 'Reducing the Difference between Citizens and Consumers: A Critical Discourse Analysis of the Communications White Paper 2000', Networking Knowledge 1:2 (2007).

Dawes, S., British Broadcasting and the Public-Private Dichotomy: Neoliberalism, Citizenship and the Public Sphere (London, Palgrave Macmillan, 2017).

Flew, T., 'The Citizen's Voice: Albert Hirschman's Exit, Voice and Loyalty and its Contribution to Media Citizenship debates', Media, Culture \& Society 32:6 (2009), pp. 977-994.

Freedman, D., The Politics of Media Policy (Cambridge, Polity Press, 2008).

Garnham, N., 'Public Service versus the Market', Screen 5:1 (1983).

Habermas, J., The Structural Transformation of the Public Sphere: An Inquiry into a Category of Bourgeois Society (Cambridge, Polity, 1989).

Hesmondhalgh, D., The Cultural Industries (London, SAGE, 2013), $3^{\text {rd }}$ edition.

Hind, D., The Return of the Public: Democracy, Power and the Case for Media Reform (London, Verso, 2012).

Knoll, E.M., 'The Public Value Notion in UK Public Service Broadcasting: Context of Evolving Media Policy Paradigms' (PhD Dissertation, LSE, 2012), p. 269.

Lunt, P., and Livingstone, S., Media Regulation: Governance and the Interests of Citizens and Consumers (London, SAGE, 2012).

Lunt, P., and Livingstone, S., “'Media Studies' Fascination with the Concept of the Public Sphere: Critical Reflections and Emerging Debates', Media Culture Society 35:1 (2013), pp. 87-96.

Mills, T., The BBC: The Myth of a Public Service (London, Verso, 2016).

Murdock, G., 'Communications and the Constitution of Modernity', Media, Culture \& Society 15:4 (1993), pp 521-539.

Murdock, G., 'Corporate Dynamics and Broadcasting Futures' in H. Mackay, and T. O'Sullivan (eds.) The Media Reader: Continuity and Transformation (London, SAGE, 1999), pp. 28-42.

O'Malley, T. and Jones, J. (eds.), The Peacock Committee and UK Broadcasting Policy (Hampshire, Palgrave Macmillan, 2009).

Scannell, P., 'Public Service Broadcasting and Modern Public Life', Media, Culture \& Society 11:2 (1989).

Scannell, P., 'Public Service Broadcasting: The History of a Concept', in A. Goodwin, and G. Whannel (eds), Understanding Television (London, Routledge, 1990).

Syvertsen, T., 'The Many Uses of the “Public Service” Concept', Nordicom Review 20:1 (1999). 


\section{Sources}

Annan Committee, Report of the Committee on the Future of Broadcasting, Cm 6753 (London, HMSO, 1977).

Beveridge Committee, Report of the Broadcasting Committee, Cm 8116, (London, HMSO, 1951).

Crawford Committee, Report of the Broadcasting Committee, Cm 2599, (London, HMSO, 1926).

Communications Act (2003), http://www.legislation.gov.uk/ukpga/2003/21/contents, accessed $10 / 13 / 2020$.

DTI/DCMS, A New Future for Communications: Communications White Paper, Cm 5010 (London, HMSO, 2000), www.communicationswhitepaper.gov.uk/, accessed May 2020.

DCMS, A Public Service for All: The BBC in the Digital Age, Cm 6763, White Paper (London, London Stationery Office, 2006).

DCMS, Connectivity, Content and Consumers: Britain's digital platform for growth. Policy Paper (2013), https://www.gov.uk/government/publications/connectivity-content-and-consumers-britainsdigital-platform-for-growth accessed August 2006.

DCMS, BBC Charter Review: Public Consultation, Green Paper, (2015): https://www.gov.uk/ government/consultations/bbc-charter-review-public-consultation accessed June 2020.

DCMS, A BBC for the Future: White Paper (2016): https://www.gov.uk/government/publications/abbc-for-the-future-a-broadcaster-of-distinction, accessed June 2020.

Hunt Committee, Report of the Inquiry into Cable Expansion and Broadcasting Policy, Cm 8679 (London, HMSO,1982).

Ofcom, Review of Public Service Television Broadcasting (2004), http://stakeholders.ofcom.org.uk/ broadcasting/reviews-investigations/public-service-broadcasting/?a=0, accessed May 2020.

Ofcom, Digital PSB: Public Service Television Broadcasting post Digital Switchover (2006), http:// stakeholders.ofcom.org.uk/broadcasting/reviews-investigations/public-service-broadcasting/ digitalpsb/, accessed June 2020.

Peacock Committee, Report of the Committee on Financing the BBC, Cm 9824 (London, HMSO, 1986).

Pilkington Committee, Report of the Committee on Broadcasting, Cm 1753 (London, HMSO,1962).

Sykes Committee, Broadcasting Committee: Report, Cm 1951, (London, HMSO, 1923).

Ullswater Committee, Report of the Broadcasting Committee, Cm 5091, (London, HMSO, 1936).

\section{NOTES}

1. P. Scannell, 'Public Service Broadcasting: The History of a Concept', in A. Goodwin, and G. Whannel (eds), Understanding Television (London, Routledge, 1990).

2. S. Dawes, British Broadcasting and the Public-Private Dichotomy: Neoliberalism, Citizenship and the Public Sphere (London, Palgrave Macmillan, 2017).

D. Hind, The Return of the Public: Democracy, Power and the Case for Media Reform (London, Verso, 2012).

T. Mills, The BBC: The Myth of a Public Service (London, Verso, 2016).

3. T. Syvertsen, 'The Many Uses of the "Public Service" Concept', Nordicom Review 20:1 (1999). 
4. D. Freedman, The Politics of Media Policy (Cambridge, Polity Press, 2008), pp. 13-14.

D. Hesmondhalgh, The Cultural Industries (London, SAGE, 2013), $3^{\text {rd }}$ edition, p. 123.

5. R. Collins, 'Paradigm Found: The Peacock Report and the Genesis of a New Model of UK Broadcasting Policy', in T. O'Malley and J. Jones (eds.) The Peacock Committee and UK Broadcasting Policy (Hampshire, Palgrave Macmillan, 2009), p. 148.

6. Hesmondhalgh, The Cultural Industries, p. 129.

7. J. Curran, and J. Seaton, Power without Responsibility: The Press, Broadcasting, and New Media in Britain, (London, Routledge, 2003), $6^{\text {th }}$ edition.

8. Hesmondhalgh, The Cultural Industries.

9. Ibid.

10. Curran, and Seaton, Power Without Responsibility: The Press, Broadcasting, and New Media in Britain.

G. Murdock, 'Communications and the Constitution of Modernity', Media, Culture \& Society 15:4 (1993).

11. Curran, and Seaton, Power Without Responsibility: The Press, Broadcasting, and New Media in Britain, p. 34.

12. J. Curran, Media and Power (London, Routledge, 2002), p. 304.

Murdock, 'Communications and the Constitution of Modernity', p. 533.

13. Curran and Seaton, Power Without Responsibility: The Press, Broadcasting, and New Media in Britain, p. 303.

14. Hesmondhalgh, The Cultural Industries, p. 142.

15. G. Born, 'From Reithian Ethic to Managerial Discourse: Accountability and Audit at the BBC', Javnost: The Public 10:2 (2003).

16. S. Dawes, 'Reducing the Difference between Citizens and Consumers: A Critical Discourse Analysis of the Communications White Paper 2000', Networking Knowledge 1:2 (2007).

Born, 'From Reithian Ethic to Managerial Discourse: Accountability and Audit at the BBC'.

G. Murdock, 'Corporate Dynamics and Broadcasting Futures' in H. Mackay, and T. O'Sullivan (eds.) The Media Reader: Continuity and Transformation (London, SAGE, 1999), pp. 28-42.

17. S. Barnett, 'Which End of the Telescope? From Market Failure to Cultural Value', in J. Cowling and D. Tambini (eds), From Public Service Broadcasting to Public Service Communications (Institute for Public Policy Research, 2002), p. 32, www.ippr.org, accessed 01 June 2009.

18. Freedman, The Politics of Media Policy, p. 158.

19. Ibid., p. 149.

20. Ibid., p.169.

21. G. Born, Uncertain Vision: Birt, Dyke and the Reinvention of the BBC (London, Vintage, 2005).

22. Barnett, 'Which End of the Telescope? From Market Failure to Cultural Value'.

23. T. Flew, 'The Citizen's Voice: Albert Hirschman's Exit, Voice and Loyalty and its Contribution to Media Citizenship debates', Media, Culture \& Society 32:6 (2009), pp. 977-994.

P. Lunt and S. Livingstone, Media Regulation: Governance and the Interests of Citizens and Consumers (London, SAGE, 2012).

24. Ofcom, Review of Public Service Television Broadcasting (2004), http:// stakeholders.ofcom.org.uk/broadcasting/reviews-investigations/public-service-broadcasting/? $\mathrm{a}=0$, accessed 05 May 2020.

25. Born, 'From Reithian Ethic to Managerial Discourse: Accountability and Audit at the BBC', p. 104.

26. See, for instance, the debates considered in the Beveridge Committee, Report of the Broadcasting Committee, $\mathrm{Cm} 8116$ (London, HMSO, 1951).

27. P. Lunt and S. Livingstone, “'Media Studies' Fascination with the Concept of the Public Sphere: Critical Reflections and Emerging Debates', Media Culture Society 35:1 (2013), p. 90. 
28. J. Habermas., The Structural Transformation of the Public Sphere: An Inquiry into a Category of Bourgeois Society (Cambridge, Polity, 1989).

29. R. Collins, 'Public Service versus the Market Ten Years on: Reflections on Critical Theory and the Debate on Broadcasting Policy in the UK', Screen 34:3 (1993), p. 246-247.

30. P. Scannell, 'Public Service Broadcasting and Modern Public Life', Media, Culture \& Society 11:2 (1989).

31. Murdock, 'Corporate Dynamics and Broadcasting Futures', pp. 28-42.

32. Curran and Seaton, Media and Power, p. 303.

33. Sykes Committee, Broadcasting Committee: Report, Cm 1951 (London, HMSO, 1923), p. 13.

34. Ullswater Committee, Report of the Broadcasting Committee, Cm 5091 (London, HMSO, 1936), p. 40.

35. R.H. Coase, 'The Origin of the Monopoly of Broadcasting in Great Britain', Economica 14:55 (1947), p. 209.

36. Sykes Committee, Broadcasting Committee: Report, p. 6.

37. Ibid., pp. 30-31.

38. Pilkington Committee, Report of the Committee on Broadcasting, Cm 1753 (London, HMSO, 1962), p. 18.

39. Ibid.

40. Ibid., p 17.

41. Ibid., pp. 17-18.

42. Ibid., p. 158.

43. Ibid., p. 286.

44. Hunt Committee, Report of the Inquiry into Cable Expansion and Broadcasting Policy, $\mathrm{Cm} 8679$ (London, HMSO, 1982), p. 1.

45. Ibid., p. 34 .

46. Ibid., p. 3.

47. DTI/DCMS, A New Future for Communications: Communications White Paper, Cm 5010 (London, HMSO, 2000), p. 32, www.communicationswhitepaper.gov.uk/, accessed May 2020.

48. Peacock Committee, Report of the Committee on Broadcasting, p. 122.

49. Ibid., p. 130.

50. Ibid., p. 125.

51. Ibid., pp. 130-131.

52. Ibid.

53. Ibid., p. 37.

54. Ibid., p. 130.

55. Ibid., p. 148.

56. Ibid., p. 131.

57. Ibid., p. 132.

58. Ibid., p. 130.

59. Ibid., pp. 130-133.

60. Ibid., p. 126.

61. Ibid., p. 133.

62. Ibid., p. 151.

63. Ibid., p. 133

64. Ibid.

65. Ibid.

66. Collins, 'Paradigm Found: The Peacock Report and the Genesis of a New Model of UK Broadcasting Policy'.

67. Ofcom, Review of Public Service Television Broadcasting.

68. Ibid. 
69. Ofcom, Digital PSB: Public Service Television Broadcasting post Digital Switchover (2006), p. 3, http://stakeholders.ofcom.org.uk/broadcasting/reviews-investigations/public-servicebroadcasting/digitalpsb/, accessed 8 June 2020.

70. Ibid., p. 26.

71. Ibid., p. 6.

72. DCMS, A Public Service for All: The BBC in the Digital Age, Cm 6763, White Paper (London, London Stationery Office, 2006), p. 34.

73. Ibid., p. 2.

74. Ibid., p. 3.

75. DCMS, A BBC for the Future: White Paper (2016): https://www.gov.uk/government/ publications/a-bbc-for-the-future-a-broadcaster-of-distinction, accessed June 2020.

76. DCMS, A Public Service for All: The BBC in the Digital Age, Cm 6763, White Paper (London, London Stationery Office, 2006), p. 34.

77. Ibid.

78. D.J. Lee, K. Oakley, and R. Naylor, “"The Public Gets what the Public Wants"? The Uses and Abuses of "Public Value" in Contemporary British Cultural Policy', International Journal of Cultural Policy 17:3 (2011), p. 292.

79. DCMS, Ibid., 2005, 2006.

80. DCMS, Digital PSB: Public Service Television Broadcasting Post Digital Switchover, p. 32.

81. Collins, 'Paradigm Found: The Peacock Report and the Genesis of a New Model of UK Broadcasting Policy', p. 8.

82. D.J. Lee, K. Oakley, and R. Naylor, “"The Public Gets what the Public Wants"? The Uses and Abuses of "Public Value" in Contemporary British Cultural Policy', p. 291.

83. R. Collins, 'Digital Television in the United Kingdom', Javnost: The Public 9:4 (2002), p. 8.

84. Ibid., p. 293.

85. E.M. Knoll, 'The Public Value Notion in UK Public Service Broadcasting: Context of Evolving Media Policy Paradigms' (PhD Dissertation, LSE, 2012), p. 269.

86. Ibid., p. 291.

87. Knoll, 'The Public Value Notion in UK Public Service Broadcasting: Context of Evolving Media Policy Paradigms'.

88. DCMS, A BBC for the Future: White Paper.

89. Ibid., pp. 57-65.

\section{ABSTRACTS}

This article will focus on the evolving rationale for broadcasting regulation and understandings of the national interest in the UK, deconstructing the ongoing reconfiguration of the terms 'public service' and 'public interest', as well as 'public control' and 'public value', within regulatory documents, to argue that there has been an increasing marginalisation and reconstruction of the notion of 'public service' in favour of an approach that privileges competition above all else.

A partir de l'analyse des textes réglementaires, cet article explore l'évolution des logiques qui ont façonné le cadre régulateur qui a régi le secteur de l'audiovisuel britannique. L'intérêt sera ainsi d'identifier les manières dont le concept d'intérêt national a pu être appréhendé. Il s'agira 
également d'étudier la reconfiguration actuelle des concepts de "régulation publique » et de "valeur publique ", afin de démontrer comment la notion de 'service public' a été sans cesse reconstruite avant d'être de plus en plus marginalisée, pour laisser la place à une approche qui par-dessus tout, privilégie la concurrence.

\section{INDEX}

Mots-clés: $\mathrm{BBC}$, régulation publique, intérêt public, service public, sphère publique, valeur publique

Keywords: $\mathrm{BBC}$, public control, public interest, public service, public sphere, public value

\section{AUTHOR}

\section{SIMON DAWES}

Simon Dawes is senior lecturer in British politics and cultural industries at the Universite de Versailles Saint-Quentin-en-Yvelines. He is the author of British Broadcasting and the Public-Private Dichotomy: Neoliberalism, Citizenship and the Public Sphere (London, Palgrave Macmillan, 2017) and the editor of the journal, Media Theory. 